
$\varphi_{0}$

$\mathrm{PO}_{4}$ $4_{k}$ 40 

Digitized by the Internet Archive in 2011 with funding from University of Toronto 




\section{CONTRIBUTIONS OF THE}

\section{ROYAL ONTARIO MUSEUM OF ZOOLOGY}

No. 12: ONTARIO AND ITS AVIFAUNA. By L. L. SNyder AND

THE MUSEUM'S BIRD COLlECTiON, By J. L. Baillie

(Adapted from the papers read at the Toronto meeting of the American Ornithologists' Union, 1935)

Published under

THE REUBEN WELLS LEONARD BEQUEST 



\title{
ONTARIO AND ITS AVIFAUNA
}

\author{
By L. L. SNYDER \\ Extent, Physiography and Vegetational Features
}

$\mathrm{T}$

HE Province of Ontario embraces a total of 412,582 square miles. Perhaps a better appreciation of its size is given by describing it as about equal to the combined areas of Maine, Vermont, New York, Pennsylvania, Ohio, Indiana, Michigan, IVisconsin and Minnesota. Its east-west spread reaches from eastern New York State to western Minnesota, and it is more than a thousand miles in a straight line from the extreme southern boundary to the north-west point on Hudson Bay. Besides having more than six hundred miles of salt-water coast line, it borders all of the Great Lakes except Michigan.

The succession of geological changes which have taken place in Ontario has affected to a notable degree the distribution and relative proportions of its present-day bird fauna. Somewhere in the neighbourhood of seventy-five per cent. of the provincial area is covered by hard rocks, mostly granite and gneiss of Precambrian age. This occupies the middle section, all but the far north and the more southern counties. The slow erosion of these rocks and the periodic scouring of their surfaces by at least five successive ice sheets have prevented or disrupted the formation of deep soils. Drainage is largely a matter of basin overflows in youthful stages and is altered considerably by the filling in of vegetation. Consequently, Ontario is notoriously a land of deep, clear and cold lakes, bogs, relatively siltless rivers and rock hills of low or moderate relief. The area has become occupied by a bird fauna in accordance with these conditions. As an example of groups which for ecological reasons are but poorly represented as breeding birds of the region, one might mention the duck family.

In southern portions of the province and in the extreme north, deposits of sedimentary rocks were laid down in invading seas. In southern Ontario, the products of disintegration of these comparatively soft rocks, together with the drift from glaciers, have formed deep rich soils in a latitude favourable to agriculture. Some agricultural land, the so-called Clay belt, exists partly on the Precambrian shield and partly on the sedimentary rocks north of the 
height of land, as a result of deposits formed in glacial lake Ojibway, but extensive cultivation is largely limited to southern sections.

Ontario is still principally a forested area, although fires and cutting have affected great tracts. In the thousand miles of its north-south extent, there is sufficient progressive change of climatic conditions to produce four forest types worthy of name-the southern hardwoods (which occur as relic stands in the cultivated sections of the south), the mixed forest, the eastern coniferous forest and the sub-arctic forest. They may be further subdivided on the basis of the effects of climate, soil and drainage conditions. Fragments of treeless areas are to be found along the exposed coast of Hudson Bay.

From this brief sketch of the physiographic and vegetational conditions prevailing in Ontario, it should be understood that the large number of avian forms which can be ascribed to the area is consequent to its length-breadth extensiveness rather than to any pronounced and general environmental diversity. As a matter of fact, vast tracts of remarkably uniform ecological conditions prevail, and more or less characterize the bulk of the province.

\section{Life Zones and Faunal Areas}

Some indication of the writer's present interpretation of the life zones and faunal areas in Ontario, based largely on animal distribution, may be given here in brief (see map 1). Along the north shore of Lake Erie, in extreme southern Ontario, the Carolinian fauna of the Austral life zone is fairly dominant. This fauna drops out as one proceeds northward, continuing as an important element farthest north, along the shore of Lake Huron. The Alleghanian faunal area, of the Transition life zone, overlaps the Carolinian inland from Lake Erie and gradually gains ascendancy northward, reaching its purest condition in the Lake Simcoe region but does not die out until after the Sault Ste. Marie-Lake Nipissing line is passed. In the western portion of the province, from Port Arthur to Kenora, there is a notable influence of the Assiniboian fauna of the Canadian life zone. The Canadian life zone overlaps the Transition zone across the province from Rainy River District to Lake Nipissing, the overlap being interrupted by Lake Superior. From this belt northward, however, a characteristic Algonquin fauna prevails to a line somewhere through central Patricia and southern James Bay. Hudsonian conditions probably begin locally and extend beyond this line over the coastal plain of Hudson Bay. Also, it seems probable that small areas more or less characteristically Arctic may be found locally along the exposed points and shores of Hudson Bay. 


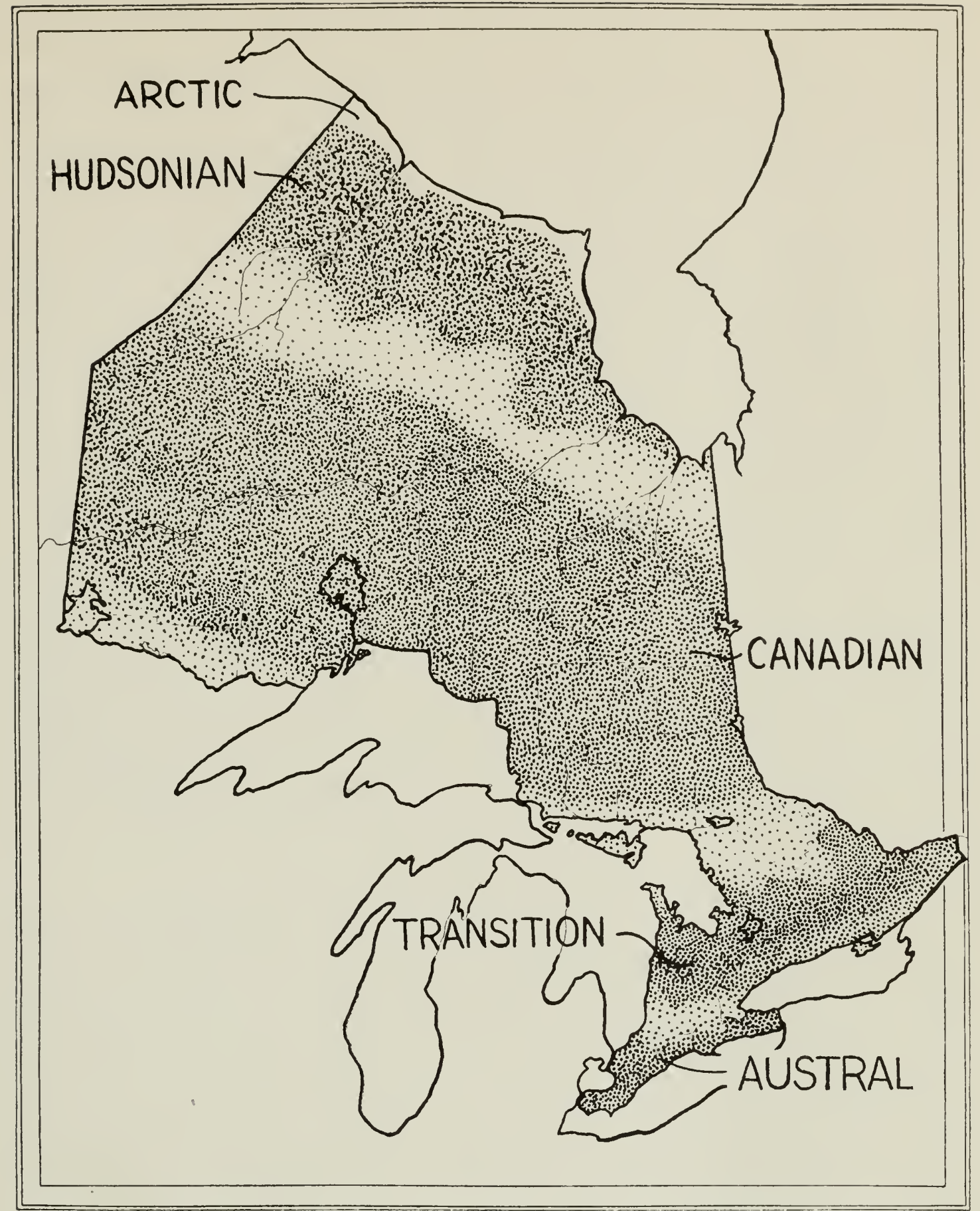

MAP 1. Life zones in Ontario.

\section{Changes in Avifauna}

Apart from short-period fluctuations in the population totals of our birds, there is no doubt that the avifauna of the province has changed and is continuing to change in respect to ratios and area occupied. The clearing of the land and other environmental alterations which accompany the development of agriculture and 
industry are usually regarded as principal causes. To make a generalized statement, certain field birds have increased and expanded their ranges, and the numbers and distribution of certain forest forms have been curtailed or interrupted. Specific examples which illustrate the former are the Bobolink (Dolichonyx oryzivorus) and the Eastern Meadowlark (Sturnella magna) while the Pileated Woodpecker (Ceophloeus pileatus) and the Spruce Grouse (Canachites canadensis) are examples of the latter. A few species such as the Western Meadowlark (Sturnella neglecta) and the Cardinal (Richmondena cardinalis) are known to be comparatively recent additions to our avifauna, their advent not being caused directly by man. The Ring-necked Pheasant (Phasianus colchicus) and the European Partridge (Perdix perdix), however, are definite introductions. And then, change has been wrought by the extirpation of certain species, the Passenger Pigeon (Ectopistes migratorius) and the Wild Turkey (Meleagris gallopavo).

The most remarkable novelty in the matter of our changing avifauna is the Starling. During a running survey made in the summer of 1935 , nearly sixteen hundred miles were traversed in southern Ontario. The Starling was found to be the third most evenly distributed and numerous bird. The Song Sparrow and Robin exceeded it. South of Lake Simcoe, the Starling exceeded all other species, both in point of numbers and in regular distribution. This has come about in approximately sixteen years!

\section{An Analysis of Ontario's Avifauna}

'To turn to a brief analysis of Ontario's avifauna, it may be remarked that a complete list of Ontario birds cannot be compiled with certainty, but there are about $342+$ species, residents and transients, which occur or have occurred in our area. A total of two hundred and forty-seven species, based for the most part on actual records, appears to be a fairly exact estimate of the summer resident or breeding species. Of this total, four species are exotics which have been introduced and have become established. Of the two hundred and forty-three native species, continental or wide-ranging forms constitute $28 \%$. The more characteristically boreal birds make up $35 \%$. Species which reach the northern periphery of their range in Ontario and represent southern elements constitute $27 \%$. Western forms to the extent of $10 \%$ reach and penetrate into the province most pronouncedly in the region west of Lake Superior. Western forms do occur as a minor element in the north, in the south-central (vicinity of Sault Ste. Marie) and in the extreme south (counties bordering on Lake St. Clair and Lake Erie). 
Field Work by the R.O.M.Z.

Although contributions to our knowledge of Ontario birds began nearly two centuries ago and, strangely enough, dealt with

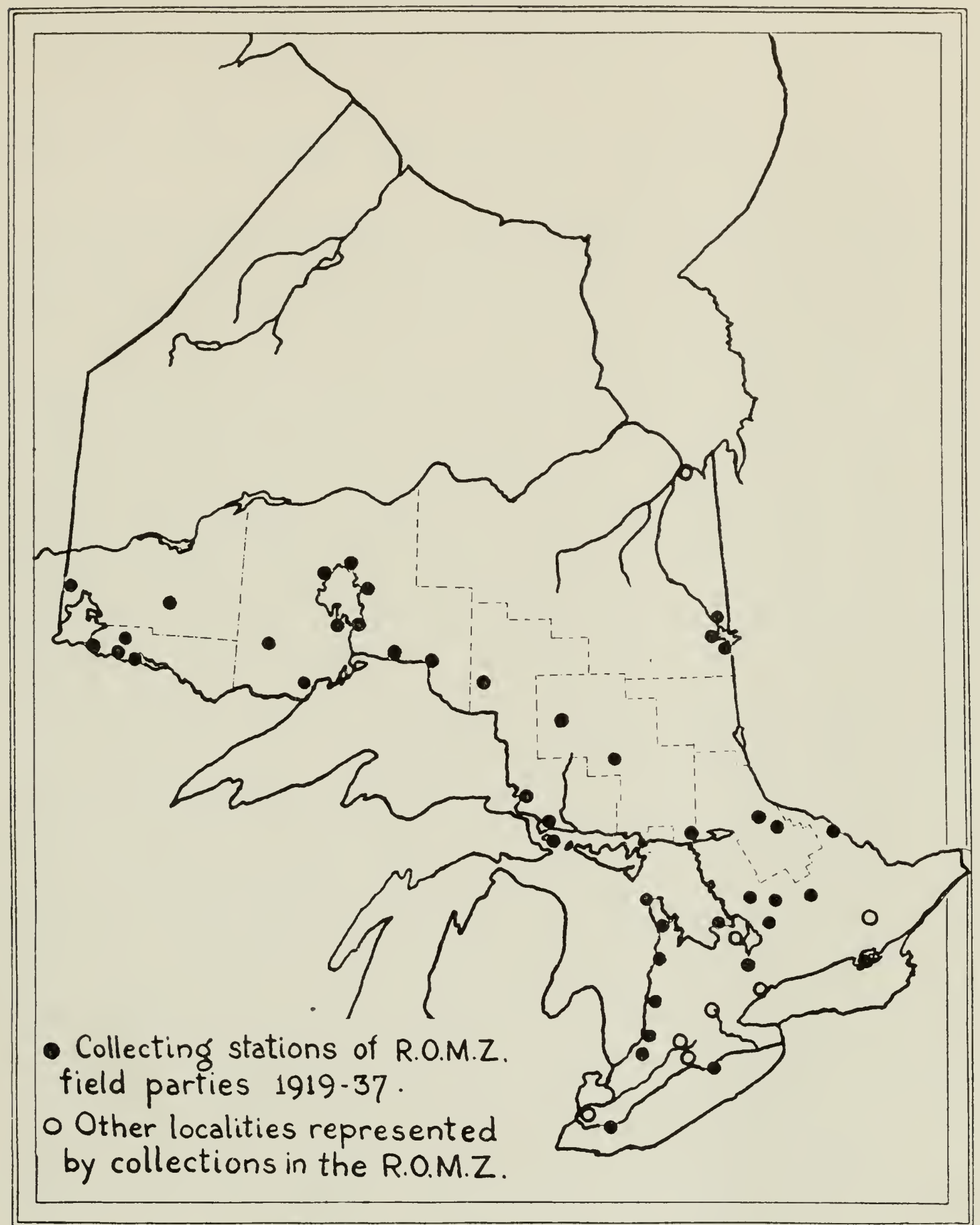

MaP 2. Distribution of the Museum's Ontario collections.

the far north, which is still difficult of access, vast areas are still unsurveyed. Only a few years ago, it was estimated that $90 \%$ of the published literature on Ontario birds pertained to the southern 
$10 \%$ of the provincial area. Although this situation is improving rapidly and field work is well in advance of publication, extensive areas have yet to be investigated.

Some iclea of this Muscum's contribution to this work may be gained by a brief review of its field activity during the past eighteen years (see map 2). Particular attention has been given to summer resident or breeding birds of the province. These are the forms which can be regarded more strictly as Ontario birds. They are the birds tied to our area during the most important period of the year, the period of reproduction.

Prior to 1923, the Museum made casual observations on birds in several areas: in 1919, on the north branch of the Muskoka river, Muskoka District; 1920 at Point Pelee, Essex County; 1922 in northern Algonquin Park.

In 1923, the Museum undertook to carry on a survey as a systematic programme, the exact place and duration of field work to be adjusted each year according to the funds available. A survey of the Lake Nipigon region was conducted during 1923 and completed the following summer. In 1925, work was continued, at Lake Abitibi. In 1926, a survey of King Township was prosecuted. During the summer of the following two years, 1927 and 1928, Long Point, Norfolk County, was the scene of a survey. In 1929, an expedition worked the western portion of Rainy River District. The following summer, 1930, work was conducted in both Prince Edward and Bruce counties. In 1931, the region of Sault Ste. Marie, Algoma District, was investigated.

After a lapse of three years, during which little field work was done, expeditions were resumed in 1935 , when a party covered approximately sixteen hundred miles of southern Ontario as a running survey. In 1936, work was carried on between Schreiber and Amyot on the north-east shore of Lake Superior. In 1937, field work was conducted in two sections, one party working between Ingolf (on the Manitoba-Ontario boundary) and Fort William, and the other party between Chapleau and the French river.

These surveys have greatly enlarged our knowledge of birds in Ontario, and through them, approximately 5,000 specimens have been added to the Museum's study collection. Further work is contemplated. With the development of provincial ornithology will come the basis for broader studies. 


\title{
THE MUSEUM'S BIRD COLLECTION \\ (with an account of early Ontario Ornithology)
}

\author{
By J. L. BAillie
}

\section{Early Ornithologists and Collections}

Although the earliest recorded observations on Ontario birds were those made by Samuel de Champlain (Macnamara, 1926) on the north shore of Lake Ontario in September, 1615, no important contribution to Ontario ornithology was made until 1768. During that year, Andrew Graham, Governor of the Hudson's Bay Company's post at Severn River on Hudson Bay, submitted (Preble, 1902) a number of birds to the Royal Society (England), collected by him along Ontario's sea-coast. The importance of Graham's work can be estimated when we consider that from this collection were described the Eskimo Curlew (from Fort Albany), the Great Gray Owl, the White-crowned Sparrow, the Blackpoll Warbler and the Hudsonian Chickadee (from Severn River), none of which had previously been brought to the attention of the scientific world.

Humphrey Martin, Governor of Fort Albany on James Bay (1775?-1782?), sent to England several hundred specimens of "animals and plants" collected in the vicinity of the Fort, at the request of his Company, but nothing further is known of his work or whether or not any birds were included in his collection.

T. Hutchins, who succeeded Martin as Governor of Fort Albany, made even more extenisive collections at Hudson Bay and his manuscript journals (235 pages of which are devoted to birds) written about 1782 and entitled "Observations on Hudson's Bay" are still in the library of the Company, unpublished. They contain descriptions of the habits and occurrence of birds noted during his twenty-five years' residence at Albany and Severn (particularly at the mouth of the Severn River).

Following Hutchins came Charles Fothergill (1782-1840), whose manuscript on the birds of the north shore of Lake Ontario contains carefully-written descriptions of 117 species of birds, with copious notes on their occurrence and abundance. Fothergill, whose residence in southern Ontario extended from 1817 to the time of his death in 1840 , may well be regarded as the first individual to deal particularly and fully with Ontario birds. His jour- 
nal, dealing with Upper Canada birds, is still in the possession of one of his great-grandsons, Major C. A. MacGillivray, of Oshawa, Ontario.

The next Ontario ornithologist of note was IVilliam Pope (1811$1902)$, who, during his residence near Port Ryerse, Norfolk County, painted pictures of 162 species of native bircls. These paintings, as well as a typewritten copy of one of his journals (covering the period from 1834 to 1843), are now in the Public Reference Library, Toronto. Many of his paintings compare favourably with our best modern depictions of birds, and they are of particular interest by reason of their early date. By far the best of Pope's paintings (59 species) were done between 1834 and 1847. These are bound in one volume in the Reference Library. The others, framed in the John Ross Robertson Historical Room in the Library, illustrate 149 species. These are for the most part dated from 1859 to 1875 and are distinctly inferior to his earlier efforts.

Although Graham, Hutchins, Fothergill and Pope were the pioneers of Ontario ornithology, none of them published any account of their observations or collections. Graham's collections were described by Forster (1772); Hutchins' manuscript has been extensively quoted by Latham (1781-5), Pennant (1784-5), Swainson and Richardson (1831), and Thompson (1890); Fothergill's journal has been reported on by Black (1934) and a catalogue of Pope's paintings has been published by the Toronto Public Library (1917).

The first attempt to write a list of the birds of Ontario was in 1822 (37 species), followed by lists in 1851 ( 72 species), 1859 (145 species), 1867 (271 species), 1886 (296 species), 1893 (322 species), 1894 (309 species), 1900 (300 species) and 1905 (315 species), compiled successively by Gourlay, Smith, Cottle, Hincks, McIlwraith, Fleming and Nash (Baillie and Harrington, 1936).

\section{The R.O.M.Z. Collection of Birds}

In 1835, Fothergill, who was a member of the Legislative Assembly (1S25-9) during his residence in Upper Canada, proposed the establishment of a museum of natural history at Toronto, and succeeded in procuring a grant of land from the government for the purpose. Fothergill accumulated a large collection of stuffed birds for this proposed museum but these, together with most of his journals, were destroyed by fire shortly after his death in 1840 .

The Royal Ontario Museum of Zoology collection of birds is in some respects an outgrowth from the Biological Museum of the University of Toronto. The earliest serious attempt to bring together a bird collection at the University was made in 1853 by Rev. 
William Hincks, first professor of Natural History (1853-71), just thirteen years following Fothergill's death.

The control of the Biological Museum was officially taken over by the Senate of the University on August 11, 1856, and the bird collection developed by Hincks and his successors, Professor H. A. Nicholson (who occupied the chair, 1871-74) and Professor Ramsay Wright (1874-1912). It contained 783 birds in 1865 (Hincks' inventory), 1190 birds in 1870, 3,547 birds in April, 1909 (according to an inventory made by the late J. B. Williams, cataloguer of the Museum, 1906-1916) and approximately 5,000 birds on October 16, 1913, when the Royal Ontario Museum of Zoology was established.

The new museum enlarged the scope for building a research collection of birds and the Biological Museum's collection served as the nucleus. A list of the major sub-collections contained in this early collection is appended to this paper (table 1), but it here suffices to say that it contained important lots from Dr. J. H. Garnier, the British Museum, J. H. Ames and the Biological Society of Ontario, acquired between 1891 and 1912.

Following the transfer of the Biological Museum collection in 1913, the next considerable acquisitions were made in 1922 and 1924, when the J. E. Keays and the C. B. Garrett collections of bird-skins, totalling more than 2,300 specimens, were acquired.

In 1933, two notable collections were added,- - the collection of the Ontario Provincial Museum (founded in 1853) and a generic collection. The former was presented by the Ontario government and the latter purchased with funds bequeathed by the late Colonel Reuben Wells Leonard, formerly a trustee of the Royal Ontario Museum. These two lots contained nearly 2,700 birds and were world-wide in representation.

Staff collecting (which has added more than 5,000 specimens to the collection since 1919), the increasing number of acquisitions and the development of ornithological work in the Museum brought the total collection in 1933 up to 21,500 specimens (Peters, 1933) and in 1935 necessitated the establishment of a Division of Birds, with curatorial supervision.

Since then the collection has grown to 28,892 specimens (December, 1937), a total exceeded in Canada only by the Fleming collection at Toronto (which housed 33,000 specimens in 1933) and perhaps by the collection of the National Museum of Canada (Peters, 1933) at Ottawa (25,000 specimens in 1933).

The growth of the collection is indicated by the following inventories, taken at various times since the Museum was established in 1913 : 
The geographical representation of the bird collection is as follows, in approximate numbers: North America, 23,000; South America, 1,900; Asia, 1,600; Europe, 1,000; Africa, 700 and Australia, 400. Of the North American series, which approximates 80 per cent. of the total collection, the major representation is as follows: Ontario, 15,000; British Columbia, 1,700; Manitoba, 1,100; Alberta, 400; California, 400; Utah, 400; Alaska, 250 and Michigan, 200.

All of the 27 avian orders are represented in the collection, 160 of the 166 families, 1,655 genera and 3,305 species. About two thousand of the birds (1,050 species) are mounted and on exhibition. Included in the collection is a small number of alcoholic specimens and a quantity of dry skeletal material. There is also a collection of approximately 2,800 sets of eggs and nests.

The collection is arranged according to Wetmore's classification (1934) with the genera and species arranged in accordance with Peters (as far as published, 1931-7) and Sharpe's (1899-1909) lists. The research collection is housed in 92 specially-designed metalcovered cabinets of three sizes, as described by Snyder (1935), in a Bird Room (see accompanying illustration) of 1,850 square feet, especially provided for the purpose in the new fire-proof Museum building, officially opened on October 12, 1933. 


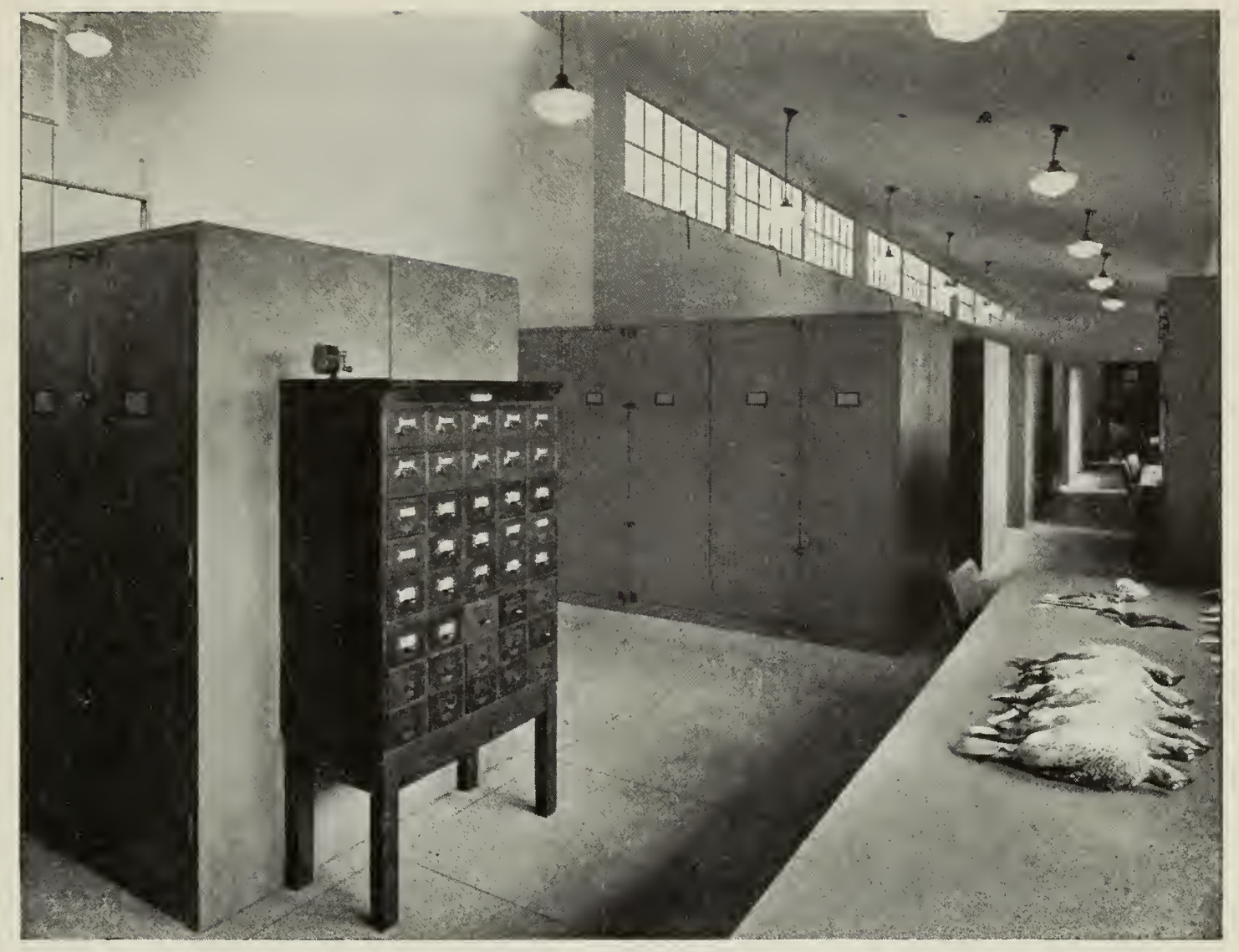

View of the Museum's bird room, 1935. 
TABI.Y: 1.-Principal Collections of Birds in the R.O.M.Z.

\begin{tabular}{|c|c|c|c|}
\hline Date acquired & $\begin{array}{c}\text { Number } \\
\text { of } \\
\text { birds }\end{array}$ & From whom & Description \\
\hline 1913 (Oct.). & 5,000 & $\begin{array}{l}\text { Biological Museum, } \\
\text { Univ. of Toronto }\end{array}$ & $\begin{array}{l}\text { Containing ten major lots as follows, } \\
\text { with the date of their receipt: } \\
\text { Prior to } 1870 \text {-about } 300 \text { old mounted } \\
\text { birds } \\
1891 \text { (Feb.)-104 specimensfrom Paris } \\
\text { Museum } \\
1891 \text { (Oct.)-612 specimens from Dr. } \\
\text { J. H. Garnier } \\
1895 \text { (Nov.)-108 skins from Malabar } \\
\text { coast, India, from Wm. Boultbee } \\
1901 \text { (Oct.)-1,619 specimens from } \\
\text { British Museum (Natural History) } \\
1904 \text { (Apr.)-114 Ontario skins from } \\
\text { R. T. Anderson } \\
1904 \text { (Nov.) - } 166 \text { mounted Ontario } \\
\text { birds from Lady Gzowski } \\
1911 \text { (Mar.)-546 specimens from } \\
\text { J. H. Ames, mostly from Ontario but } \\
\text { including } 86 \text { skins from British } \\
\text { Guiana } \\
1911 \text { (Apr.)-113 mounted Ontario } \\
\text { birds from Rev. John Doel } \\
\text { 1912 (Jan.)-1,047 Ontario skins from } \\
\text { Biological Society of Ontario, includ- } \\
\text { ing lots from J. Edmonds (390), } \\
\text { Dr. W. Brodie (159), W. Metcalfe } \\
\text { (141), W. G. A. Brodie (109) and } \\
\text { G. E. Atkinson (101). }\end{array}$ \\
\hline $1914-23$. & 736 & James Goldie & $\begin{array}{l}\text { Skins, including about } 200 \text { humming } \\
\text { birds }\end{array}$ \\
\hline 1916 (May). & 240 & F. Norman Beattie & $\begin{array}{l}\text { Skins from Guelph, Ont., and Van- } \\
\text { couver, B.C. }\end{array}$ \\
\hline $1916-37$. & 172 & $\begin{array}{l}\text { Toronto Parks De- } \\
\text { partment }\end{array}$ & Captive birds \\
\hline $1918-37$ & 74 & Paul Hahn & Including 50 Passenger Pigeons \\
\hline 191 & 5,366 & R.O.M.Z. staff & $\begin{array}{l}\text { Skins, mostly from Ontario, secured } \\
\text { during the Museum's avifaunal sur- } \\
\text { vey of the province }\end{array}$ \\
\hline 1922 (Apr.) & 1,307 & J. E. Keays & $\begin{array}{l}\text { Skins, mostly from Middlesex County, } \\
\text { Ontario }\end{array}$ \\
\hline $1923-37$ & 668 & A. A. Wood & $\begin{array}{l}\text { Skins, mostly from Middlesex County, } \\
\text { Ontario }\end{array}$ \\
\hline 1924 (Apr.) & 1,082 & C. B. Garrett & $\begin{array}{l}\text { Skins, from Alberta and British Col- } \\
\text { umbia }\end{array}$ \\
\hline 1924 (May) & 284 & Hubert H. Brown & Skins, mostly from Toronto, Ontario \\
\hline $1924-5 \ldots \ldots$ & 181 & H. S. Osler & Skins from Anglo-Egyptian Sudan \\
\hline
\end{tabular}


TABle 1.-Continued

\begin{tabular}{|c|c|c|c|}
\hline Date acquired & $\begin{array}{c}\text { Number } \\
\text { of } \\
\text { birds }\end{array}$ & From whom & Description \\
\hline $1924-5$ & 522 & $\begin{array}{l}\text { Royal Canadian In- } \\
\text { stitute }\end{array}$ & Mostly from Toronto, Ontario \\
\hline $1924-37$. & 125 & Robt. V. Lindsay & $\begin{array}{l}\text { Mostly from Frontenac County, On- } \\
\text { tario }\end{array}$ \\
\hline $192 t-37$. & 206 & J. A. Munro & Skins, mostly from British Columbia \\
\hline 5 (Nov.) & 90 & J. A. Varley & Skins, mostly from Toronto, Ontario \\
\hline $1925-37 \ldots$ & 175 & Holton B. Haugh & Skins, mostly from Barrie, Ontario \\
\hline $5-37$. & 177 & J. H. Fleming & Including 96 hummingbirds \\
\hline 1926 (Feb.) & 220 & John Boyd & Skins from southern Ontario \\
\hline 1926 (Mar.) & 133 & Major E. H. Pooler & Skins from Ramandrug, India \\
\hline $1926-33 \ldots$ & 809 & John Maughan. Jr. & $\begin{array}{l}\text { Skins from Toronto, Ontario, and } \\
\text { mounted foreign birds }\end{array}$ \\
\hline 192 & 605 & Alfred & Skins from Port Sydney, Ontario \\
\hline & 307 & Racey & Skins from British Columbia \\
\hline & 207 & $\begin{array}{l}\text { Dr. C. H. Douglas } \\
\text { Clarke }\end{array}$ & Skins from southern Ontario \\
\hline 192 & 126 & Dr.W.Ellis Hurlburt & Captive birds (exotics) \\
\hline & 250 & Jack Miner & $\begin{array}{l}\text { From Kingsville, Ontario, including } \\
163 \text { hawks and owls }\end{array}$ \\
\hline $1929-$ & 312 & Dr. W. E. Saunders & $\begin{array}{l}\text { Casualties from Long Point, Ontario, } \\
\text { lighthouse }\end{array}$ \\
\hline $1929-3$ & 682 & Clifford E. Hope & $\begin{array}{l}\text { Skins, mostly from York and Peel } \\
\text { Counties, Ontario }\end{array}$ \\
\hline 1930 (Mar.) & 145 & Dr. & Skins, mostly fron California \\
\hline 1930 (May) & 481 & $\begin{array}{l}\text { Dr. A. Brooker } \\
\text { Klugh }\end{array}$ & $\begin{array}{l}\text { Skins, mostly from Essex, Wellington } \\
\text { and Bruce Counties, Ontario }\end{array}$ \\
\hline 193 & 479 & A. Gow Estate & Skins, mostly from Windsor, Ontario \\
\hline $1930-3$. & 59 & Rev. C. L. W. Bailey & $\begin{array}{l}\text { Skins from Lake Harbour, Baffin } \\
\text { Island, N.W.T. }\end{array}$ \\
\hline & 112 & H. South & Skins from southern Ontario \\
\hline & 489 & & From Lake St. Martin, Manitoba \\
\hline $1931-7$. & 383 & Arthur C. Twomey & Skins, mostly from Churchill, Man. \\
\hline 1932 (Aug.) & 450 & W. G. A. Lambe & Skins, mostly from southern Ontario \\
\hline $1932-3$ & 596 & Dr. J. E. H. Kelso & $\begin{array}{l}\text { Skins, from British Columbia (397), } \\
\text { and Hants, England (199) }\end{array}$ \\
\hline & 497 & & Skins, mostly (405) from Utah \\
\hline $1932-7$ & 57 & Reginald V. Whelan & From Cochrane District, Ont. \\
\hline 1933 (June) & 1,392 & $\begin{array}{l}\text { Ontario Provincial } \\
\text { Museum }\end{array}$ & $\begin{array}{l}\text { Built up through the efforts of C. W. } \\
\text { Nash and J. Maughan, Jr., mostly } \\
\text { from Toronto but containing } 175 \\
\text { skins from Moosonee, Ont., collected } \\
\text { by Sam Waller }\end{array}$ \\
\hline 1933 (Sept.). & 1,345 & $\begin{array}{l}\text { Col. Reuben Welis } \\
\text { Leonard Estate }\end{array}$ & $\begin{array}{l}\text { A generic collection of skins, pur- } \\
\text { chased from W.F. H. Rosenberg }\end{array}$ \\
\hline $1933-\overline{7}$ & 136 & W. Herbert Lunn & $\begin{array}{l}\text { Mostly from Prince Edward County, } \\
\text { Ontario }\end{array}$ \\
\hline
\end{tabular}


TABILE 1.-Continued

\begin{tabular}{|c|c|c|c|}
\hline Date acquired & $\begin{array}{c}\text { Number } \\
\text { of } \\
\text { birds }\end{array}$ & From whom & Description \\
\hline $19333-7$. & 118 & R. J. Gill & Captive birds (exotics) \\
\hline $1934-7$. & 58 & J. B. Robinson & Captive pheasants \\
\hline 1935 (Oct.). & 90 & William Owen & Skins, mostly from Toronto, Ont. \\
\hline 1935 (Nov.). & 128 & Euphemia Summers & Skins, mostly from Toronto, Ont. \\
\hline $1935-6 \ldots$ & 100 & Jean Bodaly & Skins from Angola \\
\hline $1935-7 \ldots$ & 58 & Major Allan Brooks & $\begin{array}{l}\text { Skins from British Columbia. Major } \\
\text { Brooks was also instrumental in } \\
\text { obtaining the Strong and Kelso col- } \\
\text { lections }(1930-3)\end{array}$ \\
\hline 1936 (Sept.). & 232 & J. F. S. Fletcher & Skins from Yakutat, Alaska \\
\hline $1936-7$. & 135 & O. D. Boggs & Skins from Peru and Ecuador \\
\hline $1936-7 \ldots \ldots$ & 45 & R. G. Ferguson & From Moosonee, Ontario \\
\hline
\end{tabular}

Table 2.-Principal Collections of Birds' Eggs in the R.O.M.Z.

\begin{tabular}{|c|c|c|c|}
\hline Date acquired & $\begin{array}{c}\text { Number } \\
\text { of } \\
\text { sets }\end{array}$ & From whom & Description \\
\hline 1913 (Oct.). & 200 & Dr. C. K. Clarke & $\begin{array}{l}\text { Acquired by the Biological Museum } \\
\text { in } 1911 \text {. Mainly from Frontenac } \\
\text { Co., Ontario }\end{array}$ \\
\hline 1923 (Mar.). & 431 & A. A. Wood & Mostly from Middlesex Co., Ontario \\
\hline 1925 (Jan.). & 168 & John L. Jackson & Mostly from Toronto, Ontario \\
\hline 1930 (June) & 650 & Edwin Beaupre & Mostly from Kingston, Ontario \\
\hline 1936 (Sept.). & 285 & F. W. Warwick & Mostly from eastern Canada \\
\hline $1936-7$. & 106 & O. D. Boggs & Mostly from Peru and Ecuador \\
\hline 1937 (Feb.) & 272 & H. V. McIntyre & Mostly from Toronto, Ontario \\
\hline 1937 (May) & 136 & Rev. C. J. Young & Mostly from southern Ontario \\
\hline
\end{tabular}




\section{LITERATURE}

1. Baillie, James L, Jr. and Harrington, Paul. 1936. The distribution of breeding birds in Ontario. Trans. Roy. Can. Inst., $21: 1$.

2. Black, R. Delamere. 1934. Charles Fothergill's notes on the natural history of Eastern Canada, 1816-1837. Trans. Roy. Can. Inst., 20: 141-68.

3. Forster, John Reinhold. 1772. An account of the birds sent from Hudson's Bay. Philos. Trans. London, 62: 370-81 (as reprinted by the Willughby Soc., 1882).

4. Latham, John. 1781-5. A general synopsis of birds.

5. Macnamara, Charles. 1926. Champlain as a naturalist. Can. Field-Nat., 40:131.

6. Pennant, Thomas, 1784-5. Arctic zoology.

7. Peters, James Lee. 1931-7. Check-list of birds of the world, 1-3.

8. Peters, James L. 1933. Collections of birds in the United States and Canadastudy collections. Fifty Years' progress of American ornithology, I883-1933: $137-8$.

9. Preble, Edward A. 1902. A biological investigation of the Hudson Bay region. N. A. Fauna, No. 22: 24.

10. Sharpe, R. Bowdler. 1899-1909. A hand-list of the genera and species of birds.

11. Snyder, L. L. 1935. Some equipment and appliances developed at the Royal Ontario Museum of Zoology. Museum News, 13, No. 10: 6-7.

12. Swainson, William and Richardson, John. 1831. Fauna Boreali-Americana, part second, the birds.

13. Thompson, Ernest E. 1890. The birds of Manitoba. Proc. U.S. Nat. Mus, 8.

14. Toronto Public Library. 1917. The J. Ross Robertson ornithological collection in the Public Library, Toronto, Ontario.

15. Wetmore, Alexander. 1934. A systematic classification for the birds of the world, revised and amended. Smithsonian Misc. Collections, 89, No. 13. 



\section{CONTR I B UTIONS \\ OF THE}

\section{ROYAL ONTARIO MUSEUM OF ZOOLOGY}

This series contains reports of Museum studies, including faunal surveys. Except where otherwise stated the price is twenty-five cents a copy.

1. Faunal Survey of the Lake Nipigon Region, Ontario, by J. R. Dymond, L. L. Snyder and E. B. S. Logier. 58 pages.

2. A Faunal Survey of the Lake Abitibi Region, Ontario, by the staff of the Royal Ontario Museum of Zoology. 46 pages.

3. A Faunal Investigation of King Township, York County, Ontario, by L. L. Snyder and E. B. S. Logier. 42 pages (out of print).

4. A Faunal Investigation of Long Point and Vicinity, Norfolk County, Ontario, by L. L. Snyder and E. B. S. Logier. 120 pages (out of print).

5. Some Account of the Amphibians and Reptiles of British Columbia, by E. B. S. Logier. 26 pages (out of print).

6. A Study of the Sharp-tailed Grouse, by L. L. Snyder. 66 pages.

7. The Passenger Pigeon in Ontario, by Margaret H. Mitchell. Records of the history of the now extinct wild pigeon (Ectopistes migratorius) in Ontario. Paper, \$1.00. Cloth, \$1.50.

8. The Distribution of Breeding Birds in Ontario, by James L. Baillie, Jr., and Paul Harrington. 134 pages.

9. Some Freshwater Fishes of British Columbia, by J. R. Dymond. 14 pages.

10. The Birds of the Lake St. Martin Region, Manitoba, by T. M. Shortt and Sam Waller. 51 pages.

11. Baird's Sparrow, by B. W. Cartwright, T. M. Shortt and R. D. Harris. 44 pages.

12. Ontario and its avifauna, by L. L. Snyder, and The museum's bird collection, by J. L. Baillie. 14 pages. 

H.

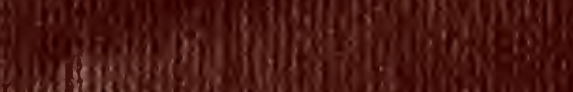

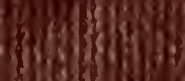

1.

(5) 